\title{
Wewenang Pemerintah dalam Pembubaran Organisasi Masyarakat
}

\author{
Emanuel Raja Damaitu \\ Universitas Katolik Widya Karya, Indonesia \\ emanuel_fh@widyakarya.ac.id \\ Igam Arya Wada \\ Universitas Katolik Widya Karya, Indonesia \\ igamaryawada@gmail.com
}

\begin{abstract}
Civil Society Organization (CSO) is an organization founded and formed by the community voluntarily based on the similarity of aspirations, wills, needs, interests and objectives to participate in development in order to achieve the objectives of the Unitary State of the Republic of Indonesia (NKRI). But many established organizations are not based on the common vision and mission required by the government. The emergence of a number of radical organizations that perform anarchist actions make people feel uneasy about the actions of mass organizations that commit acts of violence by using the pretext of religion as a justification reason. The Government in this case has considerable authority in Law No. 17 of 2013 on Civil Society Organizations where the ultimate estuary is the revocation of registered certificate which affects the dissolution of problematic community organizations. With the authority granted to the government, it is suggested that the government should be able to crack down on mass organizations which generate problematic causes and break public orders.
\end{abstract}

KEYWORDS: Government Power, Dissolution Of Civil Society Organization, Right to Association.

Copyright $\odot 2017$ by Author(s)

This work is licensed under a Creative Commons Attribution-ShareAlike 4.0 International License. All writings published in this journal are personal views of the authors and do not represent the views of this journal and the author's affiliated institutions.

\section{HOW TO CITE:}

Damaitu, Emanuel Raja \& Igam Arya Wada. "Wewenang Pemerintah dalam Pembubaran Organisasi Masyarakat" (2017) 4:3 Lentera Hukum 157-170.

Submitted: September 13, 2017 Revised: September 14, 2017 Accepted: September 17, 2017 


\section{IMPLEMENTASI WEWENANG PEMERINTAH DALAM PENANGANAN ORMAS ANARKIS}

Reformasi di Indonesia telah dimulai pada saat Presiden Soeharto mengundurkan diri dari pemerintahan dan digantikan oleh wakilnya yaitu B. J. Habibie pada tahun 1998. ${ }^{1}$ Terjadi perubahan yang sangat penting dalam sejarah ketatanegaraan pada saat itu, khususnya akibat adanya pemerintahan yang dapat dinilai kurang baik. ${ }^{2}$ Setelah rezim orde baru tumbang, Indonesia masuk pada masa transisi reformasi dengan menganut sistem demokrasi. ${ }^{3}$ Demokrasi sebagai dasar hidup bernegara memberi pengertian bahwa pada tingkat terakhir rakyat memberikan ketentuan dalam masalah-masalah pokok yang mengenai kehidupannya, termasuk dalam menilai kebijaksanaan negara, karena kebijaksanaan tersebut menentukan kehidupan rakyat. ${ }^{4}$ Dasar tersebut juga telah tertuang dalam konstitusi yaitu Pasal 1 ayat (2) Undang-Undang Dasar Republik Indonesia Tahun 1945 (UUD NRI 1945). ${ }^{5}$

Sejalan dengan prinsip demokrasi tersebut, perubahan UUD NRI 1945 masih berlanjut dengan pemuatan Hak Asasi Manusia (HAM) sebagai bagian dari UUD NRI 1945. Salah satu HAM yang diatur di dalam konstitusi yaitu mengenai Kebebasan berserikat dijamin di dalam pasal 28E ayat (3) UUD NRI 1945. ${ }^{6}$ Dengan dimuatnya pasal tersebut dapat dikatakan sebagai bentuk perubahan yang paling penting dalam perjalanan sejarah demokrasi Indonesia. Dengan adanya dasar hukum itu, maka setiap ormas atau kelompok-kelompok lainnya dalam melakukan aktifitasnya dilindungi oleh hukum.

Kebebasan berserikat pada masa Orde Baru diatur melalui Undang-Undang Nomor 8 Tahun 1985 Tentang Organisasi Kemasyarakatan. ${ }^{7}$ Akan tetapi, setelah beberapa lama, dapat disimpulkan bahwa sudah banyak pasal yang tidak relevan

1 Manunggal K Wardaya, Konstitusionalisme dalam dinamika negara hukum (Bandar Lampung: Indepth Publishing, 2014) hlm. 121.

2 Pemerintahan yang dinilai kurang baik adalah pemerintahan yang terlihat pada masa orde baru dijalankan dengan otoriter sehingga banyaknya pelanggaran HAM yang terjadi, serta sistem ekonomi Indonesia yang tidak stabil menyebabkan krisis moneter berkepanjangan. Lihat selengkapnya dalam Dwi Hapsari Retnaningrum et al, Aturan Hukum dan Hak Asasi Manusia (Bandar Lampung: Indepth Publishing, 2014) hlm. 5.

3 Pada masa reformasi penyempurnaan aturan dasar kehidupan berbangsa dan bernegara dibuat menjadi lebih demokratis, transparan, berkeadilan, dan sesuai dengan perkembangan dan kebutuhan jaman Lihat Selengkapnya dalam Manunggal K Wardaya, supra note $1 \mathrm{hlm} .17$.

4 MohMahfud MD, Demokrasi dan Konstitusi Di Indonesia (Jakarta: PT.Rineka Cipta, 2000) hlm. 19.

5 Di dalam pasal tersebut dinyatakan bahwa kedaulatan berada ditangan rakyat dan dilaksanakan menurut Undang-Undang Dasar

6 Di dalam pasal tersebut disebutkan bahwa setiap orang berhak atas kebebasan berserikatberkumpul, dan mengeluarkan berpendapat

7 Pada masa orde baru, pemerintah dengan ketat memberlakukan aturan penggunaan ideologi pada ormas melalui asas tunggal Pancasila yang dalam hal ini dinyatakan dalam pasal 2 ayat (l) UU No.8 Tahun 1985. Dua tahun setelah undang-undang ormas tersebut disahkan, Pelajar Islam Indonesia (PII) yang berasaskan Islam dan gerakan Pemuda Marhaenis (GPM) yang berasaskan marhaenisme dibubarkan oleh Menteri Dalam Negeri Supradjo Rustam dengan alasan menolak menyesuaikan diri dengan undang-undang ormas yang baru. Lihat selengkapnya dalam Franciska Fitri, "Mengkritisi RUU Ormas dan Potensi Pelanggaran HAM" (2015) Lemb Studi Dan Advokasi Indones ELSAM hlm. 3. 
dengan pengaturan ormas dalam undang-undang tersebut. ${ }^{8}$ Pemerintah melakukan revisi terhadap undang-undang ormas dan digantikan dengan Undang-Undang Nomor 17 Tahun 2013 (UU No.17 Tahun 2013) yang berfungsi mewujudkan tata kelola ormas, terutama yang terkait dengan transparansi dan akuntabilitas. ${ }^{9}$

Akhir-akhir ini muncul banyak sekali fenomena kekacauan yang disebabkan oleh sejumlah ormas seperti adanya bentrok antar ormas, hilangnya orang lain karena diduga ikut serta dalam suatu ormas, hingga adanya ormas yang dalam penyampaian pendapatnya tidak dilakukan dengan aksi damai dan sering sekali membuat keributan dengan aksi anarkis. ${ }^{10}$ Salah satu aksi nyata dari adanya ormas yang sering membuat keresahan di masyarakat adalah Front Pembela Islam (FPI). Semenjak dibentuknya FPI pada tahun 1998 sudah sering melakukan aksi-aksi anarkis yang meresahkan masyarakat. ${ }^{11}$

Aksi FPI sering juga berujung konflik dengan masyarakat, karena masyarakat mengganggap bahwa tidak ada surat izin yang dikeluarkan oleh pihak kepolisian terhadap aksi-aksi seperti sweeping yang dilakukan oleh FPI. ${ }^{12}$ FPI telah melewati batas kewenangannya sebagai ormas yang seharusnya menjadi fungsi dari penegak hukum yaitu Kepolisian menurut Undang-Undang Nomor 2 Tahun 2002 tentang Kepolisian Negara RI (UU No 2 Tahun 2001). ${ }^{13}$ Selain itu Pada UU No 17 Tahun 2013 juga melarang setiap ormas untuk melakukan kegiatan yang menjadi tugas dan wewenang penegak hukum sesuai dengan ketentuan peraturan perundang-undangan. Undangundang tersebut juga melarang setiap ormas untuk melakukan tindakan kekerasan, mengganggu ketentraman dan ketertiban umum, atau merusak fasilitas umum dan fasilitas sosial. ${ }^{14}$ Dari adanya kedua undang-undang tersebut sangat jelas ditunjukkan

8 Veronica Sianipar Agnes, Eddy Mulyono \& Rosita Indrayati, "TINJAUAN YURIDIS PERLINDUNGAN HUKUM HAK ASASI MANUSIA DALAM UNDANG-UNDANG NOMOR 17 TAHUN 2013 TENTANG ORGANISASI KEMASYARAKATAN" (2014), online: 〈http://repository.unej.ac.id/handle/ 123456789/59234〉 hlm. 70.

9 Ibid.

10 Mendengar kata anarkis banyak orang langsung merasa gelisah dan cemas, terbayang suatu kelompok manusia beringas yang siap menebarkan keonaran, kekacauan,dan kehancuran. Dalam memandang anarkisme, tidak hanya aparatur negara bahkan masyarakat akademisi bersepakat bahwa anarkisme adalah musuh umat manusia. Dengan demikian keyakinan yang mendominasi pemikiran masyarakat luas adalah bahwa 'anarkisme' tidak lebih dari penyakit sosial yang bertentangan dengan segala norma sosial yang baik, dan pantaslah jika anarkisme dianggap musuh masyarakat. Lihat selengkapnya dalam Rian Thera, "Analisis Hukum Terhadap Aksi Solidaritas Organisasi Masyarakat Front Pembela Islam Di Makassar Ditinjau Dari Undang-Undang Nomor 8 Tahun 1985 Juncto Undang-Undang Nomor 17 Tahun 2013 Tentang Organisasi Kemasyarakatan" (2014) Vol.3 No.1 J Ilm Mhs Univ Surabaya hlm. 8.

Il Lihat selengkapnya bukti adanya aksi anarkis FPI yang pernah dilakukan dalam "Reformata: Menyuarakan Kebenaran dan Keadilan", (2013) hlm 2. Lihat juga dalam TempoCo, "Daftar Kekerasan FPI di Lima Provinsi", online: Tempo News 〈https://m.tempo.co/read/news/2014/ 11/13/078621646/daftar-kekerasan-fpi-di-lima-provinsi>.

12 Manunggal K Wardaya, supra note $1 \mathrm{hlm} .44$.

13 Dalam pasal 2 UU No 2 Tahun 2002 disebutkan bahwa fungsi kepolisian merupakan salah satu fungsi pemerintahan negara di bidang pemeliharaan keamanan dan ketertiban masyarakat, penegakan hukum, perlindungan, pengayoman dan pelayanan kepada masyarakat

14 Lihat Pasal 59 ayat 2 huruf d UU No 17 Tahun 2013. 
bahwa apa yang dilakukan FPI dalam aksi anarkisnya nya sangat bertentangan dengan hukum yang berlaku di Indonesia.

Tidak hanya itu, FPI bahkan tak jarang juga melakukan aksi di mana dalam menyampaikan pendapatnya di muka umum dilakukan dengan cara-cara yang tidak sesuai dengan Undang-Undang Nomor 9 Tahun 1998 tentang Kemerdekaan Menyampaikan Pendapat di Muka Umum (UU No.9 Tahun 1998) bahkan juga melakukan penyerangan terhadap kelompok minoritas atas dalih agama Islam. ${ }^{15}$ Dalam penyampaian pendapatnya selama ini, FPI sering mengakhirinya dengan aksi anarkis seperti melempar batu, membawa senjata tajam dan menyerang pihak yang berwenang, serta aksi-aksi lainnya yang mengganggu ketertiban umum yang menyebabkan ketakutan serta keresahan di dalam masyarakat. ${ }^{16}$ Manunggal berpendapat bahwa sesungguhnya negara memiliki tugas untuk mewujudkan kemerdekaan dari rasa takut yang diatur dalam Pasal 28G UUD 1945. Sayangnya, bukan menjadi pengayom atau pelindung dari rasa takut terkadang sebaliknya negara juga menjadi sumber pembentuk rasa takut tersebut. ${ }^{17}$

Pada kenyataannya saat ini dalam kehidupan berbangsa dan bernegara menunjukkan bahwa masyarakat semakin tidak bebas dalam menikmati hak nya dalam beragama dan berkeyakinan, bahkan negara tidak dapat secara rasional memandang jauh kedepan bahwa sebenarnya kebijakan yang dikeluarkan tersebut menjadi legitimasi pembenar bagi suatu kelompok untuk melakukan kekerasan terhadap kelompok lain khususnya minoritas dalam negara yang demokratis. ${ }^{18}$

Salah satu kasus lain yang fenomenal dan dilakukan oleh FPI yaitu demontrasi massa yang berujung anarkis dalam rangka penolakan terhadap Basuki Tjahya Purnama (Ahok) yang dilantik menjadi Gubernur DKI Jakarta menggantikan Joko Widodo yang telah maju menjadi Presiden RI. ${ }^{19}$ FPI menolak Ahok karena dia bukan seorang muslim dan bagi FPI orang yang tidak seiman (Kafir) tidak pantas untuk memimpin Jakarta yang hampir keseluruhan warganya beragama Islam. ${ }^{20}$

Melihat aksi-aksi FPI yang berujung anarkis tersebut pada dasarnya tidak sejalan dengan tujuan berdirinya FPI. Al-Zastrouw $\mathrm{Ng}$ menjelaskan bahwa tujuan

15 Salah satu contoh penyerangan terhadap kelompok minoritas agama yang dilakukan oleh FPI adalah penyerangan terhadap kelompok ahmadiyah di ciekeusik. Lihat dalam Mark Woodward et al, "The Islamic Defenders Front: Demonization, Violence and the State in Indonesia" (2014) 8:2 Contemp Islam $153 \mathrm{hlm} .155$.

16 "Dikepungnya Markas FPI", Maj Detik (2014) 183 hlm. 12.

17 Dalam pasal 28G disebutkan bahwa setiap orang berhak atas perlindungan diri pribadi, keluarga, kehormatan, martabat, dan harta benda yang dibawah kekuasaannya, serta berhak atas rasa aman dan perlindungan dari ancaman ketakutan untuk berbuat atau tidak berbuat sesuatu yang merupakan hak asasi. Lihat juga Manunggal K Wardaya, Negara VS Ketentraman Warga (Bandung: Tribun News, 2011) hlm. 2.

18 Ibid.

19 Lihat note 16 hlm 12. Lihat juga dalam "Polisi: Aksi Anarkis FPI Saat Demo Tolak Ahok Sudah Direncanakan”, online: detiknews 〈http://news.detik.com/berita/2709813/polisi-aksi-anarkis-fpi-saatdemo-tolak-ahok-sudah-direncanakans.

20 Lihat selengkapnya dalam situs resmi FPI Front Pembela Islam Post, "Mengapa harus pemimpin muslim ?", online: 〈http://www.fpi.or.id/2016/03/mengapa-pemimpin-muslim.html’. 
terbentuknya FPI yaitu melakukan amar ma'ruf nahi munkar. ${ }^{21}$ Dalam melakukan tujuannya FPI selalu mengutamakan metode yang bijaksana dan lemah lembut melalui langkah-langkah untuk mengajak masyarakat dengan hikmah dan memberi nasihat yang baik serta berdiskusi dengan cara yang terbaik. ${ }^{22}$ Tujuan lain dibentuknya FPI adalah untuk membantu pemerintah dalam menumpas kemaksiatan. ${ }^{23}$ Meskipun FPI memiliki tujuan yang baik dalam organisasinya, tetapi pada kenyataannya dalam melakukan gerakan sesuai dengan tujuannya tersebut FPI selalu menggunakan kekerasan di tengah masyarakat dan tidak memberikan langkah-langkah damai pada setiap aksinya bahkan banyak menabrak hukum positif yang berlaku di Indonesia sebagaimana yang telah dipaparkan sebelumnya.

Jika melihat FPI secara lebih dalam lagi, akan diketahui bahwa orientasi ormas ini bukanlah pada format dan bentuk kelembagaan sesuai dengan aturan yang terdapat didalam UU No 17 Tahun $2013 .^{24}$ FPI sejak awal memang berorientasi pada gerakan untuk menumpas kemaksiatan dengan cara-cara kekerasan. ${ }^{25}$ Selain itu, sebagai ormas yang berorientasi pada gerakan agama maka gerak dan langkah ormas ini berada dibawah kendali langsung pemimpinnya. ${ }^{26}$ Dalam hal ini, seluruh anggota FPI telah didoktrin bahwa pemimpin mereka adalah para habaib dan ulama yang merupakan cerminan dari orang-orang suci dimana perintahnya tidak boleh ditentang dan perkataannya harus dilaksanakan. Jika ada anggota yang menentang maka akan dianggap sebagai penentang agama yang harus diberikan hukuman. ${ }^{27}$

Secara historis, pada dasarnya agama dapat dijadikan sebagai sebuah alat bagi masyarakat untuk merangkul persaudaraan dan juga kerja sama antaranggota masyarakat yang seiman bahkan yang berbeda agama. Namun jika jalinan persaudaraan itu tidak dipupuk dengan baik bahkan agama bisa menjadi sebuah alat penghancur

21 Amar ma'ruf nahi munkar adalah menyebarkan kebajikan dan mencegah kemungkaran berdasarakan hukum Islam dan hukum akal sehat. Lihat selengkapnya tujuan FPI pada Al-Zastrouw Ng, Gerakan Islam Simbolik: Politik Kepentingan FPI, lst ed (Yogyakarta: LKIS Pelangi Aksara, 2006) hlm 91. Abdurrachman Wahid berpendapat bahwa, ditangan ormas Radikal amar ma'ruh nahi munkar telah dijadikan legitimasi untuk melakukan pemaksaan, kekerasan, dan penyerangan terhadap siapapun yang berbeda. Sementara konsep rahmatan lil'alamin digunakan sebagai dalih formalisasi agama untuk memaksa pihak lain menyetujui tafsir mereka, dan menuduh siapapun yang berbeda dan menolak tafsir tersebut sebagai kafir. Penggunaan bahasa yang sama ini membuat mereka menjadi sangat berbahaya karena dengan bahasa yang sama mereka mudah mengecoh banyak Umat Islam. Pendapat yang disampaikan oleh Wahid, dapat membuktikan bahwa ormas Radikal memiliki interpretasi yang berbeda terhadap konsep-konsep keislaman yang tentunya sudah jauh dari esensi Islam yang sebenarnya. Lihat selengkapnya dalam Abdurrachman Wahid, Ilusi Negara Islam : Ekspansi Gerakan Islam Transnasional di Indonesia, lst ed (Jakarta: The Wahid Institute, 2009) hlm. 33.

${ }_{22} \mathrm{Al}$-Zastrouw Ng, supra note $21 \mathrm{hlm} .91$.

23 Kemaksiatan yang terjadi menurut pandangan FPI seperti misalnya maraknya praktik perjudian, narkoba, minuman keras, dan beroperasinya tempat-tempat maksiat. Lihat selengkapnya dalam Ismail Hasani, Radikalisme Agama di Jabodetabek dan Jawa Barat: Implikasinya Terhadap Jaminan Kebebasan Beragama/Berkeyakinan (Jakarta: Setara Institut, 2011) hlm 1l7. Lihat juga dalam Ibid hlm. 92.

24 Lihat Pasal 12 dan 16 UU No 17 Tahun 2013

25 Al-Zastrouw Ng, supra note 12 hlm. 93.

26 Ibid hlm. 95.

27 Ibid hlm. 96. 
yang dapat memicu konflik antarlapisan masyarakat. ${ }^{28}$ Agama memang memiliki sebuah kekuatan dalam menggerakkan setiap manusia yang memeluknya, sehingga apapun yang dilakukan oleh setiap umatnya didasarkan pada tujuan untuk mengamalkan ajaran agamanya masing-masing. Seseorang yang beragama bisa saja terlibat dalam sebuah konflik dan juga perdamaian, hal tersebut tentunya juga dapat disandarkan atas dasar pembelaan terhadap agamanya masing-masing. ${ }^{29}$ Oleh karena itu ormas yang berlandaskan agama dan melakukan serangkaian aksi-aksi anarkis dengan mengatasnamakan agama sering mendapat pandangan negatif dari masyarakat karena mengganggu kebebasan hak asasi orang lain dan tentunya juga mengganggu ketertiban umum. ${ }^{30}$

Pada dasarnya sebagai ormas yang berpijak di bumi pertiwi, FPI harus taat pada setiap aturan hukum yang telah ditetapkan oleh pemerintah. Merujuk pada teori negara hukum (rechstaat) Jimly berpendapat bahwa yang harus dijadikan panglima dalam dinamika kehidupan kenegaraan adalah hukum. ${ }^{31}$ Karena itu jargon yang sering digunakan untuk menyebut prinsip negara hukum yaitu the rule of law not a man. Selanjutnya yang disebut pemerintah pada pokoknya adalah hukum sebagai sistem, bukan orang perorang yang hanya bertindak sebagai wayang dari skenario sistem yang mengaturnya. ${ }^{32}$ Untuk itu ketika terjadi penyimpangan terhadap sistem yang telah dibuat seharusnya pemerintah menindak tegas setiap oknum yang melakukannya. Tetapi peran pemerintah dalam menghadapi ormas anarkis seperti FPI saat ini mulai dipertanyakan, alih-alih melindungi hak kebabasan orang lain yang merupakan amanat konstitusi dan salah satu elemen penting dari konsep negara hukum pemerintah justru tidak tegas dalam menindak kelompok-kelompok yang yang menggunakan kekerasan untuk mendiskriminasi serta membuat resah masyarakat. Dilatarbelakangi oleh keresahan masyarakat terhadap aksi anarkis FPI yang mengikis rasa aman, tuntutan atas pembubaran ormas anarkis menjadi mengemuka sembari pula mengecam negara yang seperti tidak mampu dan tidak mau untuk melakukan tindakan tegas untuk menegakkan hukum dan ketertiban. ${ }^{33}$ Meskipun polemik atas pembubaran ormas masih terjebak dalam perdebatan sejumlah tokoh tetapi pemerintah harus melakukan tindakan tegas dalam rangka untuk melindungi hak kebebasan masyarakat lain yang merasa bahwa kebebasannya telah direnggut oleh ormas anarkis seperti FPI yang menyebabkan rasa takut dan tidak aman di dalam negeri ini. ${ }^{34}$

Berbicara mengenai kewenangan pemerintah dalam pembubaran ormas yang tidak taat hukum, pada dasarnya aturan tersebut telah terdapat di dalam UU No. 17

28 Lea Levin, Hak-Hak Asasi Manusia (Jakarta: PT.Pradnya Paramita) hlm. 41.

29 Ibid.

30 Ibid.

31 Jimly Ashidiqie, "Konsep Negara Hukum Indonesia” (2010) Jimly Sch hlm. 1.

32 Ibid.

33 Manunggal K Wardaya, supra note $1 \mathrm{hlm} .5 \mathrm{l}$

34 Polemik tentang pembubaran ormas tersebut tidak jarang mendapat banyak komentar dari sejumlah politisi yang menyatakan penolakannya. Salah satunya yaitu Fraksi Partai Persatuan Pembangunan yang menyatakan bahwa FPI adalah aspirasi masyarakat bawah yang harus diperhatikan oleh pemerintah. Lihat selengkapnya dalam Ibid. 
Tahun 2013. ${ }^{35}$ Secara teoritis pemerintah yang mengeluarkan izin terhadap pembentukan suatu ormas menurut asas contrario actus juga berhak untuk mencabut suatu izin ketika ada pelanggaran yang dilakukan oleh suatu ormas tertentu. ${ }^{36}$ Ridwan HR dalam bukunya juga mengungkapkan tentang Teori Kewenangan yang digagas oleh F.P.C.L Tonner dimana beliau berpendapat bahwa Kewenangan pemerintah dalam kaitan ini dianggap sebagai kemampuan untuk melaksanakan hukum positif, dan dengan begitu dapat diciptakan hubungan hukum antara pemerintahan dengan warga negara. ${ }^{37}$ Oleh karena itu, sudah jelas bahwa pemerintah yang merupakan suatu lembaga yang mengatur, membuat serta, menegakkan hukum seharusnya tidak boleh kalah dan takut dengan adanya suatu ormas anarkis arena pemerintah memiliki kewenangan yang absolut dalam menindak ormas anarkis.

Meskipun terdapat kewenangan untuk membubarkan ormas anarkis, pemerintah saat ini terlihat bagaikan seekor singa yang kehilangan taringnya. Pemerintah susah untuk menerapkan kewenangannya dalam pembubaran ormas anarkis karena aksi kekerasan dan anarkis ormas yang mengatasnamakan agama meningkat, sedangkan pemerintah dan penegak hukum juga kewalahan bertindak tegas. Kurang tegasnya pemerintah dan penegak hukum dalam mengimplementasikan undang-undang mungkin saja juga disebabkan karena adanya alasan politis serta alasan-alasan tertentu. Tetapi memang, jika kita teliti pada pokoknya Tobias Basuki mengemukakan ada dua alasan mendasar yang menjadi kebingungan dan kegamangan pemerintah dalam bertindak tegas.

Pertama, adanya kontradiksi antara undang-undang yang satu dengan yang lain menjadi kegalauan para penegak hukum untuk menindak ormas karena penegak hukum juga belum terbiasa dalam menerapkan amanat konstitusi. Selain itu, juga adanya kekosongan norma pada undang-undang yang ada sehingga pemerintah tidak dapat secara tegas menindak ormas anarkis. ${ }^{38}$ Kedua, pemahaman dari konsep-konsep demokratis dalam undang-undang ormas masih merupakan sudut pandang baru, sehingga pemahaman dan konsep ini selain tidak tersirat dalam undang-undang lama juga belum digunakan dalam cara berpikir pemerintah dalam menanggapi permasalahan-permasalahan yang ada. Misalnya terlihat adanya kerancuan antara

35 Lihat pasal 62 sd 82 mengenai sanksi yang dapat dijatuhkan kepada ormas yang melanggar ketentuan larangan serta hal-hal lain yang terdapat di dalam UU tersebut

36 Dalam hukum administrasi negara asas contrario actus dapat digunakan ketika badan atau pejabat tata usaha negara menerbitkan keputusan tata usaha negara dengan sendirinya, badan atau pejabat tata usaha negara yang bersangkutan juga berwenang untuk membatalkannya. Lihat selengkapnya dalam "Menguji Ketepatan Asas Contrarius Actus dalam Perppu Ormas", online: hukumonline.com 〈http://www.hukumonline.com/berita/baca/lt596885bec2902/menguji-ketepatan-asas-contrariusactus-dalam-perppu-ormas». Dalam hal ini untuk ormas yang berbadan hukum kewenangannya berada pada kemenkumham sedangkan untuk ormas yang tidak berbadan hukum kewenangannya berada pada kemendagri sesuai dengan amanat UU No.17 Tahun 2013 dan Permendagri No.33 Tahun 2012 Tentang Pedoman Pendaftaran Organisasi Kemasyarakatan di Lingkungan Kementerian Dalam Negeri dan pemerintah Daerah.

37 Lihat pendapat Tonner dalam Ridwan,HR, Hukum Administrasi Negara (Jakarta: Rajawali Pers, 2011).

38 Tobias Basuki, "Kebebasan Berserikat Dan Perubahan Undang-Undang Ormas" (2011) Organ Masy Dalam Demokr Indones, online: 〈http://www.leimena.org/id/page/v/537/organisasi-masyarakatdalam-demokrasi-indonesià. 
melindungi hak kebebasan menjalankan agama dan hak kebebasan berserikat dan berkumpul. Pemerintah sering bingung ketika hak kelompok yang satu berbenturan dengan kelompok yang lain. ${ }^{39}$

Selain dua alasan tersebut, setelah diteliti kembali penulis memiliki alasan yang ketiga dimana hal ini merupakan alasan yang sangat subtansial dengan melihat isi dari UU No. 17 Tahun 2013. Terdapat kelemahan di dalam undang-undang tersebut, dimana dalam pasal 62 ayat (1) dan (2) dinyatakan bahwa ormas yang melanggar ketentuan undang-undang dapat dikenakan sanksi administratif berupa surat peringatan tertulis yang diberikan secara bertahap sebanyak tiga kali. Setiap surat peringatan tertulis memilki jangka waktu paling lama Tiga puluh hari pada masing-masing tahapannya. Hal tersebut menurut penulis dapat menyebabkan lolosnya ormas yang sebelumnya melanggar ketentuan undang-undang yang berlaku. Mengapa demikian? Karena dalam jangka waktu tiga puluh hari, surat peringatan tersebut dapat ditarik kembali. Setelah itu, ormas-ormas tersebut dapat melaksanakan aksinya kembali. Kemudian jika dilihat pada pasal 63 setelah jangka waktu pemberian sanksi administratif habis, jika suatu ormas melakukan kembali aksi yang melanggar ketentuan dalam undang-undang maka pemerintah wajib untuk memberikan surat peringatan tertulis yang pertama untuk kedua kalinya. Sehingga tidak dilanjutkan ke surat peringatan tertulis yang kedua atau ketiga bahkan sanksi lainnya dan jika diakumulasikan surat peringatan ini diberikan sebanyak enam kali.

Itulah yang menyebabkan pemerintah sulit untuk membubarkan suatu ormas anarkis atau ormas yang bertentangan dengan peraturan per-undang-undangan yang berlaku, karena proses pemberian sanksi yang diberikan oleh pemerintah dengan merujuk pada undang-undang tersebut sangat panjang bahkan ormas dengan sangat mudah bisa memanfaatkan kelemahan di dalam tersebut. Lalu apakah ormas tidak dapat dibubarkan untuk saat ini? Pada dasarnya secara prosedural bisa saja dibubarkan menurut ketentuan undang-undang yang berlaku, tetapi sekali lagi perlu ketegasan pemerintah, dalam menindak setiap ormas ketika diketahui telah melanggar aturan sehingga prosedur pemberian sanksi yang sangat panjang tersebut akan mudah dilalui.

Dalam konteks penanganan ormas anarkis terkait dengan aksi kekerasan yang mengatasnamakan agama sebagaimana marak terjadi dan menjadi keprihatinan banyak kalangan, maka jika suatu kepentingan nasional. Bahkan, keselamatan publik serta hak dan kebebasan orang lain terancam oleh tindakan yang mengatasnamakan suatu organisasi atau agama. Karenanya, organisasi tersebut dapat dibenarkan untuk dibatasi

39 Salah satu contoh adanya keraguan tersebut yaitu seperti dalam hal hak menjalankan kepercayaan agama, ormas keagamaan seperti FPI dan kelompok radikal lain yang selalu melakukan aksi dengan mengatasnamakan kepercayaan agama menuntut pembubaran kelompok Ahmadiyah yang dianggap sesat. Dalam hal ini terlihat Pemerintah kesulitan dan takut menyinggung kepercayaan kelompokkelompok radikal, dan malah mengabaikan hak kebebasan beragama kelompok Ahmadiyah maka dalam hal ini pemerintah membenarkan Hak kelompok mayoritas dan tidak melindungi hak kelompok minoritas padahal menurut aturan yang berlaku "setiap orang memiliki hak yang sama" untuk dilindungi menurut agama dan kepercayaannya masing-masing dan Negara sudah jelas harus melakukan perlindungan tersebut sesuai dengan amanat Pasal 29 ayat (2) UUD NRI 1945. Lihat Ibid. Lihat juga dalam Cornelis Lay, Kekerasan Atas Nama Agama Perpektif Politik (Yogyakarta: Fakultas Teologi Universitas Kristen Duta Wacana, 2009) hlm. l. 
termasuk dibubarkan dengan mendasarkan pada ketentuan peraturan perundangundangan yang berlaku serta hal ini tidak dapat dikatakan sebuah pelanggaran HAM yang dilakukan oleh Negara. ${ }^{40}$ Sebagai wujud adanya negara yang dijalankan oleh pemerintahan, maka negara harus berperan secara aktif untuk menyikapi aksi ormas yang tidak lagi sejalan dengan tujuan nasional dan mengabaikan hukum. Hal ini diperlukan sebagai penegas kewibawaan dan kemampuan negara untuk dapat mengatur, menegur, dan menertibkan warga negaranya yang tidak mematuhi serta sering menabrak aturan hukum yang berlaku di Indonesia. ${ }^{41}$

\section{PARAMETER PEMBUBARAN ORMAS ANARKIS SEBAGAI WUJUD PERLINDUNGAN HUKUM TERHADAP MASYARAKAT}

Melihat kembali pada penjelasan sebelumnya mengenai tujuan terbentukya FPI yang ternyata telah menyimpang dari tujuan umum suatu ormas agar dapat berdiri di Indonesia serta pelanggaran-pelanggaran lain yang telah dilakukan oleh FPI dengan aksi anarkisnya dalam masyarakat, hal ini dapat dianggap sebagai sebuah alasan untuk membatasi penikmatan HAM terhadapnya. Pemerintah dan penegak hukum memang ragu untuk membatasi hak untuk berserikat dan berkumpul karena hak tersebut pada dasarnya merupakan hak konstitusional dan hak fundamental warga yang tidak dapat dicabut dan telah tertuang di dalam konstitusi. Namun bagaimana pemerintah bersikap dan mengambil tindakan apabila hak tersebut digunakan oleh kelompok-kelompok tertentu yang melanggar hak konstitusional warga lainnya, dan mengancam negara? Pada dasarnya HAM tidak dapat digunakan dengan sebebas-bebasnya meskipun hak berserikat, berkumpul dan berpendapat tidak dapat dicabut, tetapi hak tersebut dapat dibatasi dengan ketentuan undang-undang yang berlaku.

Alasan tersebut dapat dijadikan pembenar dalam membatasi aktifitas atau membubarkan ormas yang bertentangan dengan aturan hukum yang berlaku. Penulis juga perlu memberikan pandangan sesuai dengan konsep pembatasan HAM agar analisis yang dilakukan oleh penulis menjadi lebih lengkap. Analisis ini juga dianggap perlu, karena banyaknya ormas anarkis saat ini telah salah mengartikan demokrasi yang berdasar pada kebebasan HAM sehingga mereka berpandangan bahwa kebebasan HAM setelah masa orde baru dapat digunakan tanpa batas. Terlebih dahulu harus ditegaskan bahwa benar jika berkumpul dalam suatu organisasi adalah bagian dari penikmatan HAM yang diatur oleh peraturan per-undang-undang yang berlaku. ${ }^{42}$ Tetapi dalam menjalankan kebebasannya setiap ormas harus tunduk pada pembatasanpembatasan HAM yang terdapat di dalam UUD NRI 1945 dan juga Undang-Undang Nomor 39 Tahun 1999 tentang Hak Asasi Manusia (UU No 39 Tahun 1999). ${ }^{43}$

\footnotetext{
40 Manunggal K Wardaya, supra note 1 hlm. 55.

41 H, Poempida, "Reposisi Organisasi Massa” (2010), online: ¿Diakses dari http://nuansabaru.com/ 2010/01/21/reposisi-organisasi-massa/>.

42 Manunggal K Wardaya, supra note 1 hlm. 53.

43 Lihat pasal 28J UUD NRI 1945 dan Pasal 70 dan 73 UU No 39 Tahun 1999.
} 
Konsep Pembatasan HAM diperlukan dalam masyarakat yang demokratis untuk menjamin keamanan nasional dan juga keselamatan publik, terutama untuk melindungi hak dan kebebasan orang lain. ${ }^{44}$ Dengan kata lain, jaminan yang diberikan oleh konstitusi adalah hanya terhadap ormas yang mampu untuk mengikuti semua aturan serta pembatasan-pembatasan sesuai dengan fungsi ormas yang terdapat di dalam UU No. 17 Tahun 2013. Lebih jauh lagi, International Covenant on Civil and Political Rights (ICCPR) juga mengatur ketika suatu negara tengah dalam keadaan darurat, kebebasan ini bahkan dapat saja dikurangi penikmatannya sebagai bagian dari apa yang disebut sebagai hak yang dapat ditunda pemenuhannya. ${ }^{45}$

Selain itu alasan lain yang dapat dijadikan pembenar untuk melakukan pembubaran terhadap keberadaan suatu ormas anarkis yaitu merujuk pada Teori Kedaulatan Negara. Kranenburg berpendapat bahwa negara adalah organisasi yang dalam suatu wilayah dapat memaksakan kekuasaannya secara sah terhadap semua golongan kekuasaan lainnya dan yang dapat menetapkan tujuan-tujuan dari kehidupan bersama itu. ${ }^{46}$ Sesuai dengan teori tersebut maka, hal ini harus direspon secara positif dengan memberikan sanksi terhadap keberadaan ormas anarkis yang telah secara jelas dan nyata telah mengganggu serta meresahkan masyarakat lainnya. Jika ormas pada setiap aksinya terlihat membahayakan kedaulatan negara, membahayakan ketertiban umum, dan juga kepentingan nasional serta melakuakan aksi yang bertentangan antara tujuan organisasi dengan pelaksanaanya dilapangan maka teori kedaualatan negara dapat dijadikan sebagai rujukan dalam pembubaran ormas anarkis.

Jika ditanyakan apa yang menjadi parameter atau tolak ukur pemerintah dalam pembubaran ormas yang dianggap meresahkan masyarakat dengan aksi anarkisnya, belum dapat dijelaskan secara umum karena bagaimana pandangan pemerintah khususnya kementerian yang berwenang dalam menangani kasus ini juga tidak dijelaskan secara rinci oleh pemerintah. Tetapi jika melihat pada aturan hukum yang berlaku serta beberapa konsep dan teori hukum yang berkembang maka akan dapat ditemukan beberapa parameter yang dapat dijadikan sebuah legitimasi terhadap pembubaran Ormas yang sering melakukan aksi anarkis serta tidak taat pada aturan hukum yang berlaku. Jika merujuk pada hal tersebut dapat penulis simpulkan ada

44 Manunggal K Wardaya, supra note 1 hlm .53.

45 Dalam article 4 ICCPR juga disebutkan bahwa "in time of public emergency which threatens the life of the nation and the existence of which is officially proclaimed" dimana hal ini mengartikan bahwa ancaman terhadap masa depan kehidupan bangsa Indonesia dan keberadaan NKRI harus dianggap sesuatu yang genting dan memaksa sehingga pemerintah harus segera melakukan tindakan untuk melindungi segenap bangsa Indonesia dari adanya ancaman yang akan berdampak pada kedaulatan negara. Penilaian mengenai ancaman terhadap NKRI tersebut juga dikuatkan dalam pasal 22 ayat (1) UUD NRI 1945. Lihat juga selengkapnya pendapat serupa yang disampaikan oleh Manunggal K. Wardaya dalam Ibid.

46 Lihat selengkapnya pendapat Krenenburg dalam Amzulian Rifai, Teori Sifat Hakikat Negara (Malang: Tunggal Mandiri, 2010) hlm. 13. Lihat juga pendapat Logeman yang menyatakan bahwa negara merupakan suatu kelompok organisasi kekuasaan/kewibawaan dalam masyarakat yang bertujuan untuk mengatur tata kehidupan yang ada di dalam masyarakat dalam EUtrech, Pengantar Dalam Hukum Indonesia (Jakarta: Penerbit dan Balai Buku Ichtiar, 1962) hlm. 360. 
beberapa parameter yang dapat dijadikan sebagai rujukan oleh pemerintah yaitu antara lain

Pertama, melihat terlebih dahulu mengenai asas, ciri, sifat dan tujuan terbentuknya suatu ormas di dalam Anggaran Dasar dan Anggaran Rumah Tangga (AD/ART) apakah bertentangan dengan aturan atau tidak. Keadaan ini dianggap sangat penting karena UU No. 17 Tahun 2013 juga menganut asas Ideologi tunggal yaitu Pancasila dan tidak boleh bertentangan juga dengan UUD 1945. ${ }^{47}$ Apabila suatu ormas dalam pendiriannya bertentangan dengan aturan hukum bahkan juga Ideologi Pancasila, maka dapat dipertimbangkan untuk dibubarkan karena dapat membahayakan kedaulatan negara. Negara dapat memberikan penilaian kepada suatu ormas dengan melihat AD/ART sebagai dasar pembentukannya. Jika bertentangan dengan UU No. 17 Tahun 2013 maka dapat dipertimbangkan untuk diberikan sanksi hukum sesuai dengan ketentuan yang berlaku. ${ }^{48}$

Kedua, melihat pada bab larangan yaitu dalam Bab XVI tentang Larangan di dalam UU No.17 Tahun 2013. ${ }^{49}$ Dengan melihat ketentuan tersebut maka akan diketahui apakah ormas tersebut melanggar pasal mengenai kewajiban ormas serta tindakan yang dilarang atau tidak. Jika ormas tersebut terbukti melanggar maka dapat dikenakan sanksi terhadap ormas yang bersangkutan sesuai dengan UU No 17 Tahun 2013 yang memuat tentang prosedur pemberian sanksi administratif seperti pemberian surat peringatan tertulis sebanyak tiga kali, pemberhentian bantuan, penghentian sementara kegiatan atau pembekuan, dan yang terakhir adalah pencabutan surat keterangan terdaftar yang implikasinya yaitu kepada pembubaran suatu ormas. ${ }^{50}$. Ketiga, menggunakan dasar Teori Kedaulatan Negara. Dalam konteks kegiatan ormas anarkis seperti FPI yang sering bertentangan dengan aturan hukum yang berlaku karena telah seringkali melakukan aksi anarkis yang dapat menyulut diintegrasi bangsa, hal ini dapat dianggap sebagai upaya yang dapat membahayakan kedaulatan negara maka pemerintah dapat menggunakan teori ini sebagai legitimasi yang sah untuk membatasi aktifitas ormas dan memberikan sanksi tegas terhadap keberadaan sebuah ormas.

Keempat, menggunakan Konsep Pembatasan HAM. Dalam hal membatasi aktifitas ormas anarkis yang dapat mengancam keamanan serta kedaulatan negara, maka Pemerintah dapat menggunakan Konsep Pembatasan HAM sebagai mana yang telah diatur di dalam UUD 1945 serta UU No.39 Tahun 1999..$^{51}$ Dalam konteks wacana pembubaran ormas terkait dengan aksi kekerasan yang mengatasnamakan agama maka jika kepentingan nasional, keselamatan publik dan kedaulatan negara nyatanya terancam oleh tindakan kekerasan yang mengatasnamakan agama, maka ormas seperti itu dapat dibatasi bahkan dibubarkan sesuai dengan peraturan perundang-undangan

47 Lihat Pasal 2 dan 3 UU No.17 Tahun 2013.

48 Lihat pada Pasal 6 UU No.17 Tahun 2013.

49 Lihat selengkapnya larangan bagi ormas dalam pasal 59 UU No.17 Tahun 2013.

50 Lihat pada pasal 60 sd 82 UU No.17 Tahun 2013.

51 Lihat pada pasal 28 J UUD 1945 dan Pasal 70 serta 71 UU No.39 Tahun 1999. 
yang berlaku. ${ }^{52}$ Pembatasan terhadap kebebasan setiap manusia dalam menjalankan hak asasinya akan mendapatkan pembenaran terlebih jika penikmatan hak dan kebebasan itu menciderai hak dan kebebasan orang lain. ${ }^{53}$

Jika pemerintah serius dalam menangani ormas-ormas anarkis seperti FPI, parameter yang telah dipaparkan diatas dalam membubarkan Ormas yang dianggap brtentangan dengan ketentuan yang terdapat diadalam peraturan perundang-undangan yang berlaku dapat dijadikan sebagai sebuah pertimbangan hukumnya. Tidak adanya ketegasan pemerintah dalam menindak ormas anarkis akan sangat membahayakan Kedaulatan NKRI suatu saat nanti. Padahal amanat UU No. 17 Tahun 2013 sudah memberikan peluang terhadap kewenangan pemerintah dalam pembubaran ormas yang melanggar ketentuan hukum. Karena tidak adanya ketegasan pemerintah dalam menghadapi aksi ormas anarkis, menyebabkan semakin banyaknya ormas serupa yang bermunculan bahkan semakin banyak anggota yang direkrut oleh ormas tersebut sehingga menyulitkan Pemerintah dalam membubarkan ormas anarkis. ${ }^{54} \mathrm{Hal}$ ini dapat membahayakan kedaulatan NKRI karena semakin banyaknya massa yang berperan dalam ormas anarkis maka akan rentan digunakan oleh pihak asing yang memiliki kepentingan terhadap Indonesia sebagai pengganti kepentingan-kepentingannya untuk menyerang kedaulatan NKRI.

\section{KESIMPULAN}

Pada implementasinya, dalam hal penanganan ormas anarkis, masalah kekerasan dan anarkisme yang timbul pada umumnya disebabkan kurang sigap dan tegasnya pemerintah dalam menangani tuntutan-tuntutan masyarakat. Selain itu lemahnya Undang-Undang Ormas yang ada, tepatnya pada bab sanksi yaitu pemberian surat peringatan tertulis, memilki jangka waktu pelaksanaan sanksi yang dapat dimanfaatkan dengan mudah oleh ormas yang ingin melanggar ketentuan yang ada di dalam peraturan perundang-undangan yang berlaku. Sebagai wujud nyata adanya negara yang dijalankan oleh pemerintahan negara, negara harus berperan aktif dalam menyikapi aksi ormas yang tidak lagi sejalan dengan tujuan nasional dan mengabaikan hukum. Dalam konteks pembubaran ormas anarkis pemerintah juga dapat melihat secara rinci aturan hukum yang terdapat di dalam UU No. 17 Tahun 2013, menggunakan dasar konsep pembatasan HAM sebagaimana yang telah diamanatkan di dalam konstitusi serta peraturan perundang-undangan lain, kemudian dalam keadaan yang dapat menyebabkan suatu kegentingan dalam NKRI negara dapat menggunakan

Manunggal K Wardaya, supra note 1 hlm. 54.

Ibid hlm. 55.

54 Banyak ormas anarkis yang bermunculan seperti Ormas Laskar Bali, Orrmas Baladika, Ormas Forum Betawi Rempug,Ormas Ormas Pemuda Pancasila, Ormas Ikatan Pemuda Karya. Serta ada juga beberapa Ormas yang tujuan organisasinya bertentangan dengan Pancasila seperti Hizbut Tahrir (HTI), Aliansi Nasional Anti Syiah (ANNAS), Jamaah Ansarut Tauhid (JAT) sehingga nantinya akan berdampak terhadap runtuhnya kesatuan dan persatuan NKRI. Lihat dalam Ismail Hasani at.all, supra note 23 . 
dasar teori kedaulatan negara untuk membatasi legitimasi keberadaan suatu ormas yang dapat membahayakan kedaulatan negara.

Berdasarkan permasalahan di atas, pemerintah harus tegas dan berani dalam hal menindak ormas yang sering melakukan aksi-aksi anarkis karena di dalam UU No. 17 tahun 2013 juga menganut asas contrario actus jadi tanpa harus menunggu semakin besarnya massa yang akan direkrut oleh suatu ormas anakis yang menggangu hak kebebasan orang lain pemerintah dapat membubarkannya. Tidak hanya FPI saja tetapi juga ormas-ormas yang sering mengatasnamakan agama untuk membuat kekacauan di negara ini dan merusak sendi-sendi NKRI. Pemerintah harus mengambil langkah preventif untuk hal ini agar tidak terjadi secara terus-menerus karena apabila tidak dicegah maka akan muncul ormas-ormas baru yang akan melakukan hal yang sama. Untuk itu pemerintah harus segera merevisi undang-undang ormas terutama pada Bab Sanksi Administratif yang berupa pemberian surat peringatan secara bertahap yang memilki jangka waktu selama tiga puluh hari hari pada setiap tahapannya. Selain itu, pemerintah harus membuat sebuah sistem data sederhana dan sangat rahasia yang memuat tentang setiap aktifitas ormas dalam rangka menghindari kerancuan atas alasan pembubaran suatu ormas ketika diketahui suatu ormas telah menyimpang dari tata aturan hukum yang berlaku. Pembubaran terhadap ormas tetap harus dilakukan dengan kehati-hatian dan melalui proses hukum (due process of law). Pertimbangan untuk membubarkan suatu ormas tetap harus menggunakan alasan yang tepat dan logis yaitu untuk kepentingan nasional dan menjaga kedaulatan NKRI.

\section{DAFTAR PUSTAKA}

Abdurrachman Wahid. Ilusi Negara Islam : Ekspansi Gerakan Islam Transnasional di Indonesia, lst ed (Jakarta: The Wahid Institute, 2009).

Al-Zastrouw Ng. Gerakan Islam Simbolik: Politik Kepentingan FPI, lst ed (Yogyakarta: LKIS Pelangi Aksara, 2006).

Amzulian Rifai. Teori Sifat Hakikat Negara (Malang: Tunggal Mandiri, 2010).

Dwi Hapsari Retnaningrum et al. Aturan Hukum dan Hak Asasi Manusia (Bandar Lampung: Indepth Publishing, 2014).

E.Utrech. Pengantar Dalam Hukum Indonesia (Jakarta: Penerbit dan Balai Buku Ichtiar, 1962).

Franciska Fitri. "Mengkritisi RUU Ormas dan Potensi Pelanggaran HAM" (2015) Lemb Studi Dan Advokasi Indones ELSAM.

Front Pembela Islam Post. "Mengapa harus pemimpin muslim?", online: 〈http://www.fpi.or.id/2016/03/mengapa-pemimpin-muslim.html〉.

H, Poempida. "Reposisi Organisasi Massa" (2010), online: «Diakses dari http://nuansabaru.com/2010/01/21/reposisi-organisasi-massa/>.

Ismail Hasani atall. Radikalisme Agama di Jabodetabek dan Jawa Barat: Implikasinya Terhadap Jaminan Kebebasan Beragama/Berkeyakinan (Jakarta: Setara Institut, 2011).

Jimly Ashidiqie. “Konsep Negara Hukum Indonesia” (2010) Jimly Sch. 
Lea Levin. Hak-Hak Asasi Manusia (Jakarta: PT.Pradnya Paramita).

Manunggal K Wardaya. Konstitusionalisme dalam dinamika negara hukum (Bandar Lampung: Indepth Publishing, 2014).

Moh.Mahfud MD. Demokrasi dan Konstitusi Di Indonesia (Jakarta: PT.Rineka Cipta, 2000).

Ridwan,HR. Hukum Administrasi Negara (Jakarta: Rajawali Pers, 2011).

Rian Thera. "Analisis Hukum Terhadap Aksi Solidaritas Organisasi Masyarakat Front Pembela Islam Di Makassar Ditinjau Dari Undang-Undang Nomor 8 Tahun 1985 Juncto Undang-Undang Nomor 17 Tahun 2013 Tentang Organisasi Kemasyarakatan" (2014) Vol.3 No.1 J Ilm Mhs Univ Surabaya.

Sianipar Agnes, Veronica, Eddy Mulyono \& 2 Rosita Indrayati. "TINJAUAN YURIDIS PERLINDUNGAN HUKUM HAK ASASI MANUSIA DALAM UNDANGUNDANG NOMOR 17 TAHUN 2013 TENTANG ORGANISASI KEMASYARAKATAN" (2014), online: 〈http://repository.unej.ac.id/handle/123456789/59234〉.

Tobias Basuki. "Kebebasan Berserikat Dan Perubahan Undang-Undang Ormas" (2011) Organ Masy Dalam Demokr Indones, online: 〈http://www.leimena.org/id/page/v/537/organisasi-masyarakat-dalam-demokrasiindonesia>.

Woodward, Mark et al. "The Islamic Defenders Front: Demonization, Violence and the State in Indonesia” (2014) 8:2 Contemp Islam 153.

"Reformata: Menyuarakan Kebenaran dan Keadilan", (2013).

"Dikepungnya Markas FPI", Maj Detik (2014) 183.

Cornelis Lay. Kekerasan Atas Nama Agama Perpektif Politik (Yogyakarta: Fakultas Teologi Universitas Kristen Duta Wacana, 2009).

Manunggal K Wardaya. Negara VS Ketentraman Warga (Bandung: Tribun News, 2011).

TempoCo. "Daftar Kekerasan FPI di Lima Provinsi", online: Tempo News 〈https://m.tempo.co/read/news/2014/11/13/078621646/daftar-kekerasan-fpi-dilima-provinsi>.

"Polisi: Aksi Anarkis FPI Saat Demo Tolak Ahok Sudah Direncanakan", online: detiknews 〈http://news.detik.com/berita/2709813/polisi-aksi-anarkis-fpi-saat-demo-tolakahok-sudah-direncanakan>.

"Menguji Ketepatan Asas Contrarius Actus dalam Perppu Ormas", online: hukumonline.com 〈http://www.hukumonline.com/berita/baca/lt596885bec2902/mengujiketepatan-asas-contrarius-actus-dalam-perppu-ormas`. 